Contemporary Journal of African Studies 2020; 7 (1): 38-46

https://dx.doi.org/10.4314/contjas.v7i1.3

ISSN 2343-6530

(C) 2020 The Author(s)

Open Access article distributed under the terms of the

Creative Commons License [CC BY-NC-ND 4.0]

http://creativecommons.org/licenses/by-nc-nd/4.0

\title{
Demands for restitution - a recent phenomenon? Early histories of human remains violations in Namibia
}

\section{Dag Henrichsen}

Head, Academic Relations and Special Projects, Basler Afrika Bibliographien Authoremail: dh@baslerafrika.ch

\section{Abstract}

Current demands by Namibian families and communities for restitution of human remains and so-called ethnographic objects in European collections are rooted in much longer traditions of restitution demands than is generally anticipated. In this paper I discuss pre- and early colonial human remains violations and African protest and resistance, which triggered principal restitution, demands and fostered a critique of colonial scientific practices, all of which resonate in current restitution politics.

Keywords: Namibia, Germany, colonialism, human remains, restitution 


\title{
Demands for restitution - a recent phenomenon? Early histories for human remains violations in Namibia
}

\author{
Dag Henrichsen
}

\begin{abstract}
Current demands by Namibian families and communities for restitution of human remains and so-called ethnographic objects in European collections are rooted in much longer traditions of restitution demands than is generally anticipated. In this paper I discuss pre- and early colonial human remains violations and African protest and resistance, which triggered principal restitution, demands and fostered a critique of colonial scientific practices, all of which resonate in current restitution politics.
\end{abstract}

Keywords: Namibia, Germany, colonialism, human remains, restitution

\section{Résumé}

Les demandes actuelles des familles et des communautés namibiennes pour la restitution de restes humains et d'objets dits ethnographiques dans les collections européennes sont enracinées dans des traditions de restitution beaucoup plus longues que ce qui est généralement prévu. Dans cet article je discute des violations des restes humains avant et au début de la colonisation et des protestations et résistances africaines, qui ont déclenché une restitution principale, qui exige et a favorisé une critique des pratiques scientifiques coloniales, qui résonnent toutes dans la politique actuelle de restitution.

Mots-clés: Namibie, Allemagne, colonialisme, restes humains, restitution

\section{https://dx.doi.org/10.4314/contjas.v7i1.3}

Dr Dag Henrichsen (dh@baslerafrika.ch) is a Namibian historian based at the Basler Afrika Bibliographien and the Centre of African Studies, University of Basel, in Switzerland. He has published extensively on Namibian history and southern African (audiovisual) archive and collection histories. 


\section{Introduction}

Restitution as a concept and process refers in a very general sense to various forms of redress for enacted injustices and violations of all sorts and includes the repatriation of artefacts, objects, documents and human remains, stolen or damaged. ${ }^{1}$ In the brief case studies presented here I use this very general framework and link this, also in a very broad sense, to acts of African protest and resistance. I focus on so-called pre- and early colonial violations by European scientists, missionaries and settlers in Namibia with regard to gravesites and other spaces imbued with spiritual meanings. My aim is to tease out local and everyday contexts in which these violations took place in order to highlight aspects of local agency, which often get lost in so-called provenance research. I argue that these early violations of the late $19^{\text {th }}$ century continue to inform, albeit in a general sense, current restitution claims as brought forward by Namibian stakeholders. In particular, these early experiences carry African traditions of critique with regard to western colonial scientific practices forward to the present (Förster et al,, 2018: $45-66)^{2}$

Recent Namibian demands for restitution have so far and almost exclusively targeted institution in Germany, the former colonial power in Namibia until 1915. To date (2019), these claims have led to several repatriations involving the return to Namibia of mostly human remains and a few individual "museum" artefacts (Pape \& Stoecker, 2018; Kössler, 2019a). These demands and repatriations took, and take place in the context of broader public debates in both Namibia and Germany as well as in the context of official negotiations between the governments of both countries concerning reparations and restorative justice with reference to the catastrophic consequences for many Namibian communities before, during and after the 1904-1908 genocidal wars and policies by the German colonial regime. So far the actual repatriations have concerned human remains and artefacts not necessarily connected to violations in the wake of the genocidal wars itself but also related to earlier or unspecific colonial and military instances of theft and violence. The following case studies refer to violent appropriations of human remains before 1904 and thus to pre- and early colonial contexts in which many African communities (with notable exceptions) 3 had not yet been confronted with large-scale colonial wars, widespread loss of human lives and destruction of livelihoods, mass detentions, forced migrations and overall land expropriation. For the case studies in question this implied that European representatives in Namibia until the 1890s had to act, in general, within complex and powerful African political and everyday frameworks, with some notable exceptions in central and southern Namibia as well as along the coastline. Furthermore, by the 1890s many African communities and individuals had gained multiple experiences in dealing with

\footnotetext{
${ }^{1}$ For the broader contexts and in relation to the German colonial contexts referred to in the following case studies, I refer to the recently published guidelines published by the German Museums Association with regard to colonial and human remains collections. (Deutscher Museumsbund, 2013; 2019).

2 These arguments have been developed initially in discussions with Larissa Förster and Holger Stoecker and were jointly published. (Förster et al, 2018). The essay here expands the empirical basis and broadens the discussion. I thank both as well as Hans fEichab for the trust in a long, ongoing collaborative research project.

${ }^{3}$ By the 1890s, the Witbooi (/Khowesen) and Khauas ( Kailkhauan) polities had already experienced large-scale violence inflicted by the German military.
} 
European missionaries, traders, settlers, scientists and officials. These broader contexts arguably shaped some of the actions in which the violations under discussion took place. ${ }^{4}$

\section{Early human remains violations: case studies}

The traceable history of human remains violations in Namibia for the sake of scientific enterprises in Europe dates back to the late 1870s and apparently starts with a missionary from the German Lutheran Rhenish Mission Society. CarlGottfried Büttner resided at the Otjimbingue mission station in central Namibia and was considered a particularly learned missionary and teacher at the mission seminary. Büttner attempted to put together a wide-ranging collection of everyday objects as produced and used by Herero people and, shortly before leaving Namibia in 1879 for good, he "bought", as he claimed, artefacts brought to him. Apparently, he had quite some success in this and could eventually ship a larger collection to Germany. In his published account he mentioned that he additionally "offered" to pay "a high price" for a human skull and/or any other human remains. He reported that nobody came forward in this respect and that his activities were now met with "anxiety" (Büttner, 1884:386-389). When finally loading the large box with his collection unto a wagon for transportation, his assistants did so only very reluctantly. Büttner published his dealings and observations in an article otherwise concerned with Herero funeral traditions and explanations concerning religious rituals with respect to the dead and the ancestors. He used his own deliberations and the reactions he encountered in order to prove the point of deep respect amongst Herero towards the dead. His arguments imply implicitly that he regarded his collecting strategies as "legitimate" for his academic endeavours and "strange" only for "the Other".

Six years later, in early 1884 , one of his possibly former students in Otjimbingue, the schoolmaster Jacobus Hendrick from the Swartbooi (IKhaulgoan) community, was killed during a raid by Herero soldiers close to the harbour settlement of Walvis Bay, together with a couple of other men (Förster et al, 2018: 45-66). A few days later Hendrick and two of the deceased men were buried by kaptein Jan Jonker Afrikander. Eight months later, in December 1884, a young German scientist, Waldemar Belck, violated these graves and shipped most of the remains of the three men from Walvis Bay to Berlin where they are kept until today in a large human remains collection owned by the Berliner Gesellschaft für Anthropologie, Ethnologie und Urgeschichte (BGAEU, Society for Anthropology, Ethnology and Pre-History). Belck and his promoter in Berlin, the acclaimed scientist Rudolf Virchow, published details of the grave robbery shortly afterwards in the Society's proceedings. The main paragraph on the robbery and about the men and their human remains reads as follows:

The affected individuals, I. Jacobus Hendrick, II. Jacobus !Garisib and III. Oantab, were killed by the Herero at a place, by the name of //Kharabes. All

\footnotetext{
${ }^{4}$ With the development of the genocidal wars in central and southern Namibia from 1904 onwards and the large-scale destruction of African societies in these regions by the German colonial regime, the overall context of "acquiring"/"collecting" any human remains and artefacts changed drastically and resulted in widespread looting and robbery by colonial agents, including medical personal. (Stoecker et al, 2018).
} 
three were Hottentots and indeed Jacobus Hendrick belonged to the Namatribe of the Zwaartboois, J. !Garisib was a cousin of Hendrick, therefore probably also Zwartbooi (if not related by marriage); I could not ascertain the tribe of Oantab, who served as a cattle guard with Hendrick. On the characteristics of J. Hendrick I also add that he was lame in one leg and was active as a schoolmaster amongst the Herero of Otyimbingue until the outbreak of war in 1880 . The bodies were buried by the Hottentot King Jan Jonker Afrikander, who passed this place shortly afterwards, that is, covered them with stones, which in the case of Oantab took place in a very incomplete manner, so that I had to search for the bones, which had been dragged away by hyenas and jackals, in a radius of a few hundred feet around. By contrast, Oantab's head, like that of J. Hendrick, was fairly well preserved. (Virchow, 1885: 317)

Elsewhere, a team of researchers including Larissa Förster, Holger Stoecker, Hans Axasi ¥Eichab and myself have published an in-depth case study about this particular grave robbery and the history of these human remains in the Berlin collection. (Förster et al, 2018: 45-66) Importantly, we could trace current family members of one of the killed men, Jacobus !Garisib. Here, I only focus on the immediate contemporary African reactions towards the grave robbery. Belck also reported that his robbery did not go unnoticed. As Virchow phrased it: "In Walfisch-Bay Mr Belck saw himself obliged to leave to the daughter of Jacobus Hendrick who had heard that the traveler brought the skeleton of her father, a skull [sic], amongst others."(Virchow, 1885: 318)

Virchow's phrasing makes clear that Jacobus Hendrick's daughter, who remains unnamed, confronted Belck with his violent actions and demanded the restitution of her father's body. The grave robbery had obviously been the subject of some kind of public discussion and as such had reached her. Virchow's statement also implies that she would not have encouraged any "exhumation" request by Belck if the latter would have considered such a request - an issue seemingly not under consideration by any European scientist "collecting" human remains in Namibia at the time. Belck clearly had no interest to consult her prior to his actions. It has also to be assumed that he had collaborators, if only with regard to information obtained about the gravesite and the names and biographies of the men whose remains he stole.

Virchow's statement also reveals that Belck, once confronted with the restitution demand by the daughter, faked restitution. According to Virchow, Belck provided the daughter with "a skull" and, it seems, only a few other human remains and thus not all the remains of her father. A close inspection of those human remains of the three men still in possession of the Berlin Society by the historian Holger Stoecker and the cultural anthropologist Larissa Förster confirmed that Belck had indeed left the daughter only with a few skeletal remains and also not with the skull of her father but, instead, the skull of Jacobus !Garisib. (Förster et al, 2018: 51) As Belck, cited above, acknowledged, the latter was in his view damaged and incomplete in contrast to the other two skulls and as such, it seemed, of less interest to him. In addition to the violation of the grave of her father the daughter of Jacobus Hendrick was thus also cheated in her demand for restitution! 
The grave robbery and restitution demand was narrated and published in Berlin in 1885 , and thus invited a broader community of scientists and scholarly readers to share in the violent and, indeed, criminal deliberations of Belck. According to my knowledge the Berlin Society has so far not scrutinized the history of the human remains of these three men nor the historical restitution demand connected to Jacobus Hendrick despite the fact that several generations of scientists have worked intermittingly with these particular human remains since 1885. (Förster et al, 2018: 54) However, the death of the three men was not forgotten in Namibia, as discussed below.

Another case of human remains violations at the time involved the Swiss botanist Hans Schinz in his travels between 1884 and 1886 to various parts of Namibia. Schinz, like Belck, robbed the remains of a man who was killed in a local skirmish in northern Namibia in late 1885. Having received information from the Finnish missionary Martti Rautanen about men who had died on a battle field near the Olukonda mission station in the Ndonga kingdom, Schinz, as he explained in a letter to his mother,

... immediately drove to the battle field the following day and [I]was so happy to find an already nearly skeletonised Ambo whom I of course took into my possession immediately and packed into a box... You actually need to collect Everything. (Henrichsen 2012: 80)

Schinz was very much aware of the fact that he transgressed local boundaries of respect and much more. He reported that he prepared the skeleton alone and out of sight of his assistants and stored the box on the roof of his ox wagon. When a storm pushed the box from the roof, the "secret", as he labelled his doings, was exposed publically. (Schinz 1891: 259-60) Shortly afterwards Schinz and the missionary also chopped off splinters from a sacred stone at a closely guarded burial site of Ndonga kings and took photographs of the spiritually imbued site. What followed after the latter incident was a veritable political crisis in the kingdom. Schinz was confronted with protest and demand for redress and restitution. The Ndonga elite (and the king's army) demanded the return of the human remains as well as the stone splinters; additionally Schinz was forced to make a compensation payment to the king's father. Like Belck, Schinz, too, resorted to cheating. He reported that he buried the skeleton and that "I have only kept the skull". (Henrichsen 2012: 143-4) He also gave back only two of the three stone splinters in his possession and thus kept one for himself. (Henrichsen 2012: 96) He then fled the kingdom whilst the homestead of his local guide to the sacred stone site was raided by the king's army. Schinz's violations in the name of science thus triggered additional violence and at least targeted the wider family of his guide.

The vast botanical, zoological and so-called ethnographic collections of Schinz reached Zurich in 1887 and were publically displayed, including the skull from northern Namibia. The Zurich newspaper, which commented on the display referred to human remains robbery as "grave desecration" and clearly being a "corpus delicti". However, it also argued that all this had been done in the name of science and as such praised Schinz as "a martyr of science" given the risks he had taken. (Henrichsen 2013: 126) Shortly afterwards the skull was sent to Berlin and entered the same collection of human remains to which Belck had contributed earlier.

\footnotetext{
${ }^{5}$ The quotation relates to the letter by Schinz dated 24 October 1885 . Capitalised and underlined in the original.
} 
As in the case of Belck's robbery, the robbery of Schinz and its repercussions, including the demands for restitution by the Ndonga elite and army, were published and were thus publically accessible for dissemination. Yet, all these details got lost, or rather, were henceforth ignored by scientists. The violently acquired human remains, once entering the Berlin collection, were now subjected to a re-definition and re-contextualisation as scientific objects of a particular kind and for the sake of physical anthropological and biometrical "race science" research. (Henrichsen 2013: 126-8) As such, the human remains were actively divorced from their contexts of origin and thus also from the - known - restitution demands linked to them. In the case of the human remains robbed by Belck, their new "status" as scientific objects remained - and remains - ambiguous as the names of two of the three deceased men had been inscribed on their skulls and are readable until today. (Förster et al, 2018: 53)

A last case of human remains violations under discussion relates to a collection of human remains put together by Eugen Mansfeld, a well-educated merchant working and living in central Namibia during the late nineteenth century. As he wrote some 40 years later in his autobiography, he collected animal trophies but also "Herero, Bergdamara, Baster, Hottentot [skulls] and even a Bushman skull". (Wellick 2017: 27) He did not explain why or how he obtained these, except for the "Bushman skull". He claimed to have received a hint about a grave in the mountains of Spitzkopje near Usakos from a local woman:

My offers of rewards for getting the skull were rejected in horror by the farm workers; and I was warned that the Bushmen would surely kill me. I wanted to have the skull, so I had to get it myself, in secret, and the same night - for I had to consider betrayal by my own natives, even if they were generally trustworthy. (Wellick 2017: 27)

Once in possession of the skull, his deliberations in his kitchen were noticed by his "good Hottentot cook" who informed him that "she would have nothing to do with this escapade, and refused to stay in the house any longer." (Wellick 2017: 28) In fact, she fled in horror!

Mansfeld kept this collection for many years and later brought it to northern Germany. To date, however, its whereabouts have not been established.

\section{The memories of horror}

In all the cases discussed here, including the case of missionary Büttner's collection strategies, African reactions can be understood as a fundamental criticism of Western purported scientific practices in the name of knowledge production right at the beginning of colonialist advancement in Namibia. Protest and resistance, in turn, did not only refer to colonial power and authority in general, and economic politics and land policies in particular, but also to "scientific" endeavours. Importantly, resistance also implied at times forceful articulation of claims and demands for redress and restitution.

Oral histories with regard to these cases reveal how the criticism, protest, resistance and even early claims for restitution continue to reverberate in the 
memories of local families and communities. In the case of Mansfeld's robbery of the "Bushman skull", local memory identifies the African cook as having been Christina / Gamiros Gorses, sister of the then Damara chief Cornelius Goreseb: "She is said to have fled Mansfeld and having walked some $80 \mathrm{~km}$ to Okombahe when she realized that the mad German at Spitzkopje killed black people and cooked their heads." (Wellick 2018: 28, iv)

In the case of Belck and his robbery of the human remains of three men, oral history today invokes a general image of colonial horror. As Hans łEichab, one of the descendants of Jakobus !Garisib, recalled in 2017:

I can vividly recall how my grandmother told us horrific stories about a raid, massacres, rapes, abductions, desecration of the dead, burials and exhumation and exportation of human remains in the lower !Khuiseb over the waters to somewhere. ... We, then as children took it up just as stories about the mythological Khoegaroen (i.e. men eaters) ..., but now I realised that it is my own flesh and blood.(fEichab, personal communication, April 28, 2017)

\section{Conclusion}

Oral histories of African families' and communities' pre- and early colonial experiences with Western science thus continue to memorialise specific violations and general perceptions of colonial violence, including western research practices. As such, the early claims for restitution, not to mention the acts of protest and resistance, inform the current restitution claims and demands by Namibian stakeholders. As argued elsewhere, scholars of provenance research have to engage with these oral histories. (Förster et al, 2018: 59) I also argue that scholars - and the political actors involved in restitution politics - would additionally need to engage with the (new) traumatic repercussions, which the very findings such as these presented here could trigger. Hans łEichab learned from us as Europebased scholars about the full history of his forefather's human remains, including the fact that: firstly, the remains of his forefather Jakobus !Garisib were robbed and continue to be "tied up" in a (deceptively addressed) historical restitution demand by Jacobus Hendrick's daughter; secondly, those remains of his forefather shipped to Germany are today no longer traceable in the Berlin collection (Förster et al, 2018: 52); and, lastly, the Berlin Society has so far not shown any interest in being pro-active in this particularly well-documented case of grave robbery, contemporary restitution demand and simultaneous restitution cheating. This case indicates that responsibilities with regard to research about the - known! - horrors of the past go well beyond a mere scholarly publication and require an engaged academic context sensitive to the repercussions of such research. Nor can any possible repatriation of human remains be the final "outcome" given the multi-layered colonial violations of both human remains and historical restitution demands. The broader frameworks of restorative justice ${ }^{6}$ with its focus on the long-term processes required to adequately address the needs of the affected families and communities are obviously at stake.

\footnotetext{
${ }^{6}$ In the related concepts of restorative and social justice, the issues of restitution, apology and reparations, as currently discussed with reference to the Namibian genocides at the beginning of the 20th century, form only part of broader, community-focused and overarching empowerment initiatives. For an introduction to the Namibian issues at stake see Kössler (2019b).
} 


\section{References}

Büttner, C. G. (1884). Die Herero und Ihre Toten. Das Ausland, 20, 386-389.

Deutscher Museumsbund (2013). Recommendations for the Care of Human

Remains in Museums and Collections. Berlin. https://www.museumsbund. de/wp-Acontent/uploads/2017/04/2013-recommendations-for-thecare-of-human-remains.pdf (accessed 24 November 2019)

Deutscher Museumsbund (2019). Care of Colonial Collections. Berlin. https:// www.museumsbund.de/wp-content/uploads/2019/09/dmb-guidelinescolonial-context-2019.pdf (accessed 24 November 2019)

Förster, L., Henrichsen, D., Stoecker, H., \& 捛hab, H.A. (2018). Re-individualising humans remains from Namibia: colonialism, grave robbery and intellectual history. Humans Remains and Violence: An interdisciplinary Journal, 4 (2), 45-66.https://doi.org/10.7227/HRV.4.2.4

Henrichsen, D. (ed) (2012). Bruchstücke. Forschungsreisen in DeutschSüdwestafrika. Briefe und Fotografien Basel: Basler Afrika Bibliographien.

Henrichsen, D. (2013). Die "Skelettaffaire" und andere "Geheimnisse" Sammlungsstrategien, Grenzüberschreitungen und Wissenskonzeptionen des Zürcher Botanikers Hans Schinz. In Stoecker, H., Schnalke, T \& Winkelmann, A. (Eds). Sammeln, Erforschen, Zurückgeben? Menschliche Gebeine aus der Kolonialzeit in akademischen und musealen Sammlungen. (pp 121-129). Berlin: Ch. Links.

Kössler, R. (2019a). The Bible and the Whip - Entaglements around the Restitution of robbed Heirlooms. ABI Working Paper, 12, Freiburg i.B. https://www. arnold-bergstraesser.de/sites/default/files/field/pub-download/kossler. the bible_the_whip_final_opdf (accessed 15 August 2019)

Kössler, R. (2019b). Postcolonial asymmetry. Coping with the consequences of genocide between Namibia and Germany. In Albrecht, M (Ed). Postcolonialism Cross-Examined. Multidirectional Perspectives on Imperial and Colonial Pasts and Colonial Present. (pp 117-134). Abingdon, Oxon: Routledge https://www.taylorfrancis.com/books/e/9780367222543 (accessed 23 November 2019)

Pape, E.., \& Stoecker, H, A. (Ed) (2018). Human Remains from Namibiain German Collections. Special issue Humans Remains and Violence: An interdisciplinary Journal, 4 (2), https://doi.org/10.7227/HRV4.2.4

Schinz, H. (1891). Deutsch-Südwestafrika. Forschungsreisen durch die deutschen Schutzgebiete Gross-Nama- und Hereroland, nach dem Kunene, dem Ngami See und der Kalahari, 1884-1887. Oldenburg: Schulzsche Hof-Buchhandlung. 
Stoecker, H., \& Winkelmann, A. (2018). Skulls and Skeletons from Namibia in Berlin. Results from the Charité Human Remains Project. Humans Remains and Violence: An interdisciplinary Journal, 4 (2), 5-26.https://doi.org/10.7227/ HRV.4.2.4

Virchow, R (1885), Sitzung vom 18.Juli 1885. Reise nach Angra Pequena und Damaraland. Zeitschrift für Ethnologie, 17, 314-325

Wellick, W. (Ed) (2017). The Autobiography of Eugen Mansfeld. A German settler's life in colonial Namibia. London: Jeppestown Press. 